\title{
Firm Performance Indicators as a Fundamental Analysis of Stocks and a Determinant of a Firm's Operation
}

Submitted 19/11/21, 1st revision 11/12/21, 2nd revision 19/01/22, accepted 20/02/22

\section{Sakchai Naknok ${ }^{1}$}

\begin{abstract}
:
Purpose: The aim is to analyze which financial instruments effectively determine firm performance as key indicators of business success and the fundamental analysis of stocks.

Design/methodology/approach: The study analyzed firm performance using financial statements for 100 listed Thailand companies via 513 observations during the period 20162020, including the economic COVID-19 crisis. The methodology was divided into two stages, at identifying the relevant dimensions of financial tools and firm size on firm performance using the ordinary least square regression logarithm. During the second stage, quantile regression was used to evaluate financial instruments as a determinant of firm performance using a set of regression functions to non-normal errors and outliers.

Findings: The ordinary least square results indicated that both the price earnings ratio and book-to-market ratio are significantly negative determinants of firm performance. The interest coverage ratio was a positive determinant of earnings per share. Meanwhile, the price earnings ratio, book-to-market ratio, and interest coverage ratio were also main determinants of firm performance in both earnings per share and return on equity in all quantiles of the firm.

Practical implications: The finding not only identifies firm performance indicators to propel an organization's capability, but also motivates that managers should make to evaluate operating results to effectively deal with a company's high performance. These indicators truly provide insight into the operation of the business by reflecting on the operation to maintain professional boundaries to earn profit that benefits both investors' decision and shareholders.

Originality/value: The novelty of this paper lies on the differently distinguished performance companies in Thailand. These investigations enrich the perception of firm performance indicators that motivate whether a company fully manages its operation to generate profit. The price earnings ratio, book-to-market ratio, interest coverage ratio, and firm size have been assessed to be outstanding indicators to contribute effective strategy of firm performance. Most investors consider fundamental value as an indicator of a firm's performance in order to investing decisions in the stock market.
\end{abstract}

Keywords: Firm performance, fundamental analysis, quantile regression.

JEL Codes: B26, D25, M21.

Paper type: Research article.

\footnotetext{
${ }^{1}$ Faculty of Management Science, Department of Economics, Valaya Alongkorn Rajabhat University under the Royal Patronage, Prathum Thani, Thailand, E-mail: sakchai@vru.ac.th
} 


\section{Introduction}

The private sector comprises of privately owned, operating-for-profit businesses. It is an important part of the economy that is run by individuals and companies for profit. The private sector is a segment of the national economy, which is owned, controlled, and managed by private individuals or enterprises. The goal of the private sector is to make money and it employs more both workers and stakeholders to competitively advance investment and increase economic growth.

The role of the private sector in Thailand has been a focus for business performance since the government engaged in regions such as South East Asia, especially in the construction business. Public policy has also focused on information sharing because Thai private sectors responded to the enhancement of Thailand's country ranking. It is important for Thai businesses with international recognition to be promoted to reach their goals for incoming investment. Private sector investment is a key driver of Thailand's economic outlook for 2019. Accordingly, increased spending in construction, health, machinery and equipment has supported growth in private investment in order to attract more investors. Thailand is working to open a new door to foreign investors by allowing foreign participation in targeted industries. (Office of the National Economic and Social Development Council, 2019).

Unfortunately, the COVID-19 pandemic caused a deep economic contraction in 2020 from a lower base in 2019 as the country suffered from the global economic slowdown. Thailand's GDP contracted by 6.1 percent in real terms in 2020. These challenges will likely continue in 2021, casting doubt on significant recovery. The private sector plays a dominant role in the economy, with private consumption and investment increasing to -2.30 percent in May from -3.10 percent in April of 2021.

Clearly, Thailand's business performance is conducive to the private sector overall, but challenges remain regarding ensuring sustainable and inclusive private sector development. The business sector in Thailand is dominated by large corporates in terms of revenue and profit (Asian Development Bank, 2021). It is important to be clear that performance for the private sector in Thailand necessarily work for business operations. A number of factors are likely to affect what type of engagement would be the most appropriate for each environment, including investment policies and procedures, legal frameworks and regulatory requirements for business registration and operations.

However, it is difficult to assess the precise impact this would have on the private sector. Much of the literature on developing economic growth has focused on the important indicator of developing perennial challenges that affect these sectors and economies that arise within this paradigm. As the drive for private sector engagement moves from firm performance determination to implementation, author would hope to see a real indicator that can determine business performance and operation as envisaged. 
The indicators of an enterprise's success measured by profitability have attracted the attention of numerous researchers investigating financial management in developing and emerging economies (Karadag, 2017; Berko and Damoah, 2013; Newman et al., 2012). The profitability index is a helpful guide to an enterprise's success and is always used as an indicator of fundamental firm performance. Firms' profitability and financial factors are of major importance for all operations of an economic system; they are a fundamental analysis that affects investors' earning comparisons of different companies, which are often analyzed using ration earnings per share (EPS).

Firm performance evaluation has become more crucial particularly since the recent economic crisis. To gain a complete picture of firms' performance, however, profitability must be combined with the level of financial leverage. More specifically, since the recent global economic crisis, both firm growth - measured by sale increase and optimum debt level has become increasingly vital, because firms may face financing operational problems as a result of an unexpected increase in country risk. There is no doubt that profitability has direct implications on shareholders, potential investors, and other interested parties, as investor and managerial perceptions of firm quality are highly related to measures of financial success, as confirmed by Deng et al. (2017), Katchova and Enlow (2013), Öner Kaya (2015).

Following previous statements, the research attempts to analyze a firm's performance using two dimensions of its profitability (dependent variables) such as return on equity (ROE), and EPS. While analyzing the determination of a firm's performance (independent variables) as fundamental operation indicators and the most important factors identifying profitability (Nunes et al., 2010), the researcher considered firm size, selling, general and administrative expenditure, and financial instruments (financial ratios) to evaluate companies' performance over time. This study then tries to explore the key indicators of firm performance using financial instruments under different quantiles of profitability to fit the regression lines with conditional quantiles and compare it with ordinary least square (OLS) estimates to visualize the robustness of the estimated statistics. Moreover, the determinants of firm performance under different quantiles of profit distribution require firm managers to motivate operation planning, including securities, as a fundamental investor analysis.

\section{Literature Review}

Most companies seek to improve their performance in any way possible. Measuring business performance is also a crucial issue for academics, practicing management term and shareholders. Regarding accounting measures, financial analysis is an important instrument of firm performance indicators to comprehend and the performance situation should be motivated. Balance sheets and income statements, during a particular period, are a core organizational database created at a specific 
moment in time. Companies analyze financial statements to reflect their performance of business operations and profitability for each accounting period. Meanwhile, most investors and creditors analyze both balance sheets and income statements to determine how well the firm operation team is utilizing a company's resources for credit and investment.

Normally, the performance evaluation of firms is conducted within the perspective of financial analysis and organizations require an accurate analysis tool with which to measure and evaluate their financial firm performance situation, especially in relation to the intensity of worldwide business competition and economic crisis (Bayrakdaroğlu and Yalçın, 2012; Zafar and Khalid, 2012; Bodhanwala and Bodhanwala, 2018).

\section{The Determinant of Firm Performance}

Profitability is mainly considered to be an important indicator for assessing the firm performance of an organization. Profitability is a ratio that can measure the performance of the company (Gitman and Zutter, 2015). Profitability analysis, as an important indicator of firm performance, indicates the clear ability of a company's financial reporting and demonstrates its ability to generate earnings for a given period by improving its profit and assets and increasing its capital stock. Firm performance assessment can be expressed by return on equity (ROE) as a proxy firm performance indicator for measuring profitability (Erina and Lace, 2013; Tailab, 2014; Katsampoxakis et al., 2015; 2018; Fara and Supartika, 2016). Profitability value is a core determinant of investor (shareholder) risk in relation to their decision to invest (Sinthupundaja and Chiadamrong, 2015). Alternatively, ROE, as a representative of firm performance indicator, expresses the shareholders who support the long-term operation and development of their firm's health and growth.

Firstly, factor that determine profitability (firm's performance) is firm size (Akotey et al., 2013; Kotey et al., 2021). According to the results of Liargovas and Skandalis (2010), financial leverage, firm size, liquidity ratio and operational ability have a significant impact on a firm's competitiveness, which can be measured using three variables: ROA, ROE and sales. Tsiapa (2021) confirmed that the operation of large firms, in terms of total asset management, and financial leverage ratio signify higher company health and profitability during arduous periods. Ayaz et al. (2021) support that both leverage ratio and firm size improve a firm's performance; this is consistent with leverage being used as an effective strategy for motivating managers to contribute greater benefits at an optimal level in Malaysian firms.

Large size of firm is likely that a lot of investors will want to buy its stock. It is clear that the size of large firms, the investing decisions of institutional investors have a greater impact on stock prices, and they are likely to be marginal price setters on the market (Locke and Mann, 2005; Venezia et al., 2011). Therefore, it is expected that companies with high profitability, usually a growth company with full performance, 
tend to have a statistically significant with the large amount of total assets growth (Constantinou et al., 2017). Moreover, Bodhanwala, and Bodhanwala, (2018) investigate the link between corporate sustainability (such as total assets, total debt to equity, and revenue growth) and the profitability of Indian firms. The results show that a firm's profitability in terms of ROE and EPS has a positive and significant relationship with its sustainability; it retains the current shareholders and encourages future shareholders to invest in the company. In addition, Kotey et al. (2021) indicate that the size increments of insurance brokerage firms positively affect the profit of stakeholders in the short term.

Assets turnover ratio has emerged as the important tool in evaluating firms' performance. Total assets turnover rate is considered as the most important factors determining the firm performance represented by ROE (Manogna et al., 2021). Alarussi and Alhaderi, (2018) empirically examined the relationship between company efficiency measured by assets turnover ratio and profitability. They show a strong positive relationship between assets turnover ratio and profitability. This result benefits for both managers, shareholders and employees to concentrate more on this factors that enhance their companies' profitability.

Other studies such as Warrad and Al Omari (2015) educated the influence of total assets turnover ratio on profitability of firms in the Jordanian during the period of 2008-2011. This study confirms a significant impact of total assets turnover ratio on the Jordanian industrial sector's profitability. This ratio assists in comparing the relative performance companies between the different industries. This is the main aim in considering the size of the company for the analysis.

The level of leverage ratios constitutes another factor that might determine the firm's performance as in measuring how much of a company's capital generates profit. From a theoretical perspective, the theory predicts that leverage has positive association with firm size, tangible assets and profitability, but has negative association with growth. Camino-Mogro and Bermúdez-Barrezueta (2019) present that interest rates as a macro variable have a negative impact on profitability. This negative relationship can be explained by the fact that higher interest rates affect the price of products and the impact of interest rate changes is a core determinant of profitability in the private sector.

Other studies focus on the determinant of firm operation and profitability are financial leverage such as Abor (2005). He found that financial leverage has significantly positive impact on a firm's profitability in the short-term. Li and Hwang (2011) also conclude that the most profitable firms correlate positively in terms of financial leverage and corporate profits. Technically, financial leverage and interest coverage ratio are calculated by dividing a company's earnings before interest and tax (EBIT) by the company's interest expenses during the same period. 
Adenugba et al. (2016) also support that financial leverage, reflects the amount of debt used in the capital structure operation of a firm, has a significant effect on a firm's performance. Thus, the benefits of debt, measured by interest coverage ratio, come from paying interest expenses, which reduce a firm's earnings and tax burden, and create an optimal capital structure that maximizes firm performance (Modigliani and Miller, 1963; Zeitun and Saleh, 2015).

Executives and managers are interested in increasing the effective use of leverage, which eventually maximizes firm performance. Investors place greater importance on gathering fundamental information about a company from economic statistics and leverage ratios before making decision to buy stocks as in Khan et al. (2017), and Karadag (2017). They investigated financial leverage in small- and medium-sized enterprises to evaluate firm performance. They strongly suggest that enterprises struggle with poor performance due to insufficient financial management. They cannot properly operate during economic challenges with respect to their profitability and overall performance.

Other factors emerged which brought about a clear contribution to firms' performance and profitability are book-to-market ratio (B/M ratio). Araújo and Machado (2018) indicate that B/M ratio, existence of firm size, and ROE can explain the variations in Brazilian stock returns. The $\mathrm{B} / \mathrm{M}$ ratio is considered a more consistent variable than firm size to estimate stock returns. According to the stock investing decisions, Clubb and Naffi (2007) explain that fundamental variables measured by the current $\mathrm{B} / \mathrm{M}$ ratio determines the inclusion of simple future $\mathrm{B} / \mathrm{M}$ estimation, return on ROE, and future stock returns on UK companies.

$\mathrm{B} / \mathrm{M}$ ratio is one of the oldest measures used in fundamental analysis and is generally utilized to differentiate between growth and value stocks (Graham and Dodd, 1934). The B/M ratio is associated with investment efficiency and company growth. In an efficient market, a company's B/M ratio should be less than 1 (B/M ratio < 1). This indicates that a firm will maximize its value by investing in the perspective of a future profitable return. In relation to this theoretical concept, de Vasconcelos and Martins (2019) analyze the relationship between B/M ratio and dividend growth rate and found that the $\mathrm{B} / \mathrm{M}$ ratio grows with the uncertainty of the average profitability of firms.

The most common ratio used by investors to determine company's performance and stock price is price earnings ratio, also known as the $\mathrm{P} / \mathrm{E}$ ratio. $\mathrm{P} / \mathrm{E}$ ratio shows how comparisons stock price compared to the company's earnings. Researchers employ a linear regression model and unanimously conclude that the $\mathrm{P} / \mathrm{E}$ ratio is positively associated with the dividend payout ratio such as Anderson and Brooks (2006), Wirjanto and Huang, (2010). The influence of P/E ratio on firm performance, Jitmaneeroj (2017a) demonstrate that the P/E ratio of firms with low payout ratio (Dividend Per Share) has a larger impact from changes in payout ratios of firms with low payout ratios (low dividend per share). 
The result is robust and concludes that the $\mathrm{P} / \mathrm{E}$ ratio is one of the most widely used indicators in stock valuation and investor decision. A lower $\mathrm{P} / \mathrm{E}$ ratio indicates that it is better for the business and for potential investors as a rapid growth of business. Investors expect higher future growth from the company compared to the overall market. Zemba and Hendrawan (2018) explain the P/E ratio value that indicate how much investors are willing to pay for income of the company in the future. Companies that have a healthy financial ratio corresponding financial theory will generate P/E measurable to the theory applies. But, Wang and Wang, (2021) point out that low $\mathrm{P} / \mathrm{E}$ ratios does not affect the long-term performance of firm. On the other hand, Thomas and Zhang, (2006) proved that there is a negative relation between earnings volatility and $\mathrm{P} / \mathrm{E}$ ratio.

In the concept of continuous improvement of a company, operating expenses (selling, general and administrative expenditure) is an essential determinant of business success and is a fundamental requirement of the competition. Company needs to identify, document, analyze and optimize quality costs. Operating cost is widely recognized as a cost factor that can significantly affect profitability (Dimitrantzou et al., 2020; Malik et al., 2016; Campanella, 1999). The significant role of operating cost in the process of continuously improvement of companies has been strongly analysed to create a high quality, and high performance of company that meets and challenges the customers' expectations (Ahmed Al-Dujaili, 2013).

Managing cost of operations of a company in the area of quality requires measuring to quality leading to their optimization in fulfilling management functions in an organization. It should be used in planning and improving firms' performance and improvement of cost activities. The company should emphasize to ensure that operating costs is effectively obtained and improved the cost management in many departments of company (Kiani et al., 2009; Biadacz, 2020).

The motivation of this study is to indicate the understanding of cost structures and points the important for firms' performance to increase proportionately revenue and profit. Team management should have concentrated efforts in operating cost of companies in order to higher profit and to remain competitive (Gunarathne and Samudrage, 2018; Anderson et al., 2003). Companies with a higher performance show a stickier cost behaviour except for selling, general and administrative expenditure to energy companies as a mechanism to keep prices low (Di Bella et al., 2015; Stimolo et al., 2019).

\section{The Objective of the Research}

The literature review discussed the importance of indicators to assess firm performance of the private sector. This study aims to identify which financial indicators, including selling, general and administrative expenditure, and size of firm effectively indicate firm performance as key indicators of business performance and success. 


\subsection{Data Collection and Description}

This study uses annual data of SET100 ${ }^{2}$ during the period 2016-2020 using the financial statements from 100 listed Thai companies through 513 observations, which took place during the COVID-19 pandemic economic crisis in 2020. These companies were selected because they were highly traded and had a more stable market value represented by high company performance. These are important private sector companies for the economy in Thailand, Southeast Asia and beyond. The sample comprised of companies listed on the SET100 as of 1 October 2021.

The firm performance data and dependent variables were comprised of EPS and ROE. To measuring firm performance, financial instruments were used including total assets turnover (TOAT), $\mathrm{P} / \mathrm{E}$ ratio, $\mathrm{B} / \mathrm{M}$ ratio, interest coverage ratio (INTE ratio), and selling, general and administrative expenditure (SGAE) including firm size (SIZE). The study employs the most important factors that influence firms' performance and commonly utilized in the previous literature. The indicator description and previous literature used in this study are listed in Table 1.

Table 1. The indicator description and previous literature.

\begin{tabular}{|c|c|c|c|}
\hline Variable & Description and indicator & Author(s) & Year \\
\hline EPS & $\begin{array}{l}\text { Earnings per share } \\
\text { EPS indicates a company's net profit } \\
\text { and presents how much money a company } \\
\text { paid for each shareholder of its common } \\
\text { stocks. }\end{array}$ & $\begin{array}{l}\text { Deng et al } \\
\text { Constantinou et al } \\
\text { Araújo and Machado }\end{array}$ & $\begin{array}{l}2017 \\
2017 \\
2018\end{array}$ \\
\hline ROE & $\begin{array}{l}\text { Return on equity } \\
\text { ROE is a measure of financial } \\
\text { performance and provides a simple metric } \\
\text { for evaluating investment returns. }\end{array}$ & $\begin{array}{l}\text { Katchova and Enlow } \\
\text { Öner Kaya } \\
\text { Nunes } \text { et al } \\
\text { Katsampoxakis et al } \\
\text { Fara, M. and Supartika } \\
\text { Sinthupundaja and } \\
\text { Chiadamrong } \\
\text { Manogna et al }\end{array}$ & $\begin{array}{l}2013 \\
2015 \\
2010 \\
2015 \\
2016 \\
2015 \\
2021\end{array}$ \\
\hline TOAT & $\begin{array}{l}\text { Total assets turnover } \\
\text { Total assets turnover is used to evaluate } \\
\text { the efficiency of management's use of } \\
\text { assets to generate the value of a company's } \\
\text { sales or revenue. }\end{array}$ & $\begin{array}{l}\text { Manogna et al } \\
\text { Alarussi, A.S., and } \\
\text { Alhaderi, S.M } \\
\text { Warrad and Al Omari }\end{array}$ & $\begin{array}{r}2021 \\
2018 \\
2015\end{array}$ \\
\hline $\mathrm{P} / \mathrm{E}$ & Price earnings ratio & Anderson and Brooks & 2006 \\
\hline
\end{tabular}

\footnotetext{
${ }^{2}$ SET100 is the top listed companies on Stock Exchange of Thailand (SET) in terms of large market capitalization, high liquidity and compliance, with requirements regarding the distribution of shares to provide a benchmark of investment in the SET toward shareholders and investors. The SET1OO index is reviewed every six months to adjust for any changes, such as new listed companies, which have occurred in the stock market. After review, new stocks that meet the necessary qualifications are selected to become part of the SET100 Index and others are removed.
} 


\begin{tabular}{|c|c|c|c|}
\hline ratio & $\begin{array}{l}\text { The } \mathrm{P} / \mathrm{E} \text { ratio is the ratio for evaluating a } \\
\text { company that measures its current share } \\
\text { price relative to its earnings per share } \\
\text { (EPS). }\end{array}$ & $\begin{array}{l}\text { Wirjanto, T.S., and } \\
\text { Huang, A.G } \\
\text { Jitmaneeroj }\end{array}$ & 2012 \\
\hline $\begin{array}{l}\mathrm{B} / \mathrm{M} \\
\text { ratio }\end{array}$ & $\begin{array}{l}\text { The book-to-market ratio } \\
\mathrm{B} / \mathrm{M} \text { ratio is used to determine the value } \\
\text { of a company by comparing its book value } \\
\text { with its market value. This ratio helps to } \\
\text { identify the overvaluation or } \\
\text { undervaluation of a firm's securities. }\end{array}$ & $\begin{array}{l}\text { Araújo and Machado } \\
\text { Clubb and Naffi } \\
\text { Graham } \text { et al } \\
\text { de Vasconcelos and } \\
\text { Martins } \\
\text { Zemba, S., and } \\
\text { Hendrawan, R. } \\
\text { Wang, Y., and Wang, G } \\
\text { Thomas, J., and Zhang, } \\
\text { H }\end{array}$ & $\begin{array}{l}2018 \\
2007 \\
1934 \\
2019 \\
2018 \\
2021 \\
2006\end{array}$ \\
\hline $\begin{array}{l}\text { INTE } \\
\text { ratio }\end{array}$ & $\begin{array}{l}\text { Interest coverage ratio } \\
\text { Interest coverage ratio is used to } \\
\text { determine the ability of a company to pay } \\
\text { the interest on its debt. It is an indicator } \\
\text { used by creditors and investors to } \\
\text { determine the risk of lending funds to a } \\
\text { company that can cover its current interest } \\
\text { payment with its available earnings and its } \\
\text { stability. }\end{array}$ & $\begin{array}{l}\text { Camino-Mogro and } \\
\text { Bermúdez-Barrezueta } \\
\text { Abor } \\
\text { Li and Hwang } \\
\text { Adenugba } \text { et al } \\
\text { Modigliani and Miller } \\
\text { Zeitun and Saleh } \\
\text { Khan } \text { et al } \\
\text { Karadag }\end{array}$ & $\begin{array}{l}2019 \\
2005 \\
2011 \\
2016 \\
1963 \\
2015 \\
2017 \\
2017\end{array}$ \\
\hline SGAE & $\begin{array}{l}\text { Selling, general and administrative } \\
\text { expenditure } \\
\text { The operating costs of running a } \\
\text { business such as advertising and marketing } \\
\text { management, and administrative to gain } \\
\text { higher company sales and profit. }\end{array}$ & $\begin{array}{l}\text { Dimitrantzou et al } \\
\text { Malik et al } \\
\text { Campanella, J } \\
\text { Ahmed Al-Dujaili, M. } \\
\text { A }\end{array}$ & $\begin{array}{l}2020 \\
2016 \\
1999 \\
2013\end{array}$ \\
\hline SIZE & $\begin{array}{l}\text { Firm size } \\
\text { Firm size refers to the efficiency and } \\
\text { extension of the growth of a firm. Size of a } \\
\text { business is important because it } \\
\text { significantly affects the efficiency and } \\
\text { profitability of the firm. }\end{array}$ & $\begin{array}{l}\text { Akotey et al } \\
\text { Kotey et al } \\
\text { Liargovas and Skandalis } \\
\text { Tsiapa } \\
\text { Ayaz et al } \\
\text { Locke and Mann } \\
\text { Venezia } \text { et al } \\
\text { Constantinou et al } \\
\text { Bodhanwala, and } \\
\text { Bodhanwala }\end{array}$ & $\begin{array}{l}2013 \\
2021 \\
2010 \\
2021 \\
2021 \\
2005 \\
2011 \\
2017 \\
2018\end{array}$ \\
\hline
\end{tabular}

Source: Own study.

In this study, the researcher employed firm performance (EPS and ROE) for SET100 firms. The financial instruments TOAT, $\mathrm{P} / \mathrm{E}$ ratio, $\mathrm{B} / \mathrm{M}$ ratio, INTE ratio including SGAE and firm size were used to measure and identify the determinants of firm performance in the model. The researcher decided to analyze the key determinants of firm performance across these variables to gain more insight into both shareholders and investors in the stock market. 


\section{Methodology}

This study aimed to identify the indicator of types of financial tools, including firm size, on firm performance. It was a crucial indicator to identify the different types of financial instruments evaluated by successful firms, and most investors used these instruments to make decision in the stock market and examining the determinant on firm performance.

The methodology was divided into two stages: the first was aimed at identifying the relevant dimensions of the financial tools and firm size on firm performance using the ordinary least square (OLS) logarithm regression. The second stage intended to examine the determinant of such financial tools and firm size in different dimensions on firm performance using an econometric model, quantile regression.

\section{Econometric Model}

The OLS regression approach requires the assumptions of homoscedasticity and the normal distribution of the error term. The quantile regression approach $(\mathrm{QR})$ presents several advantages compared to conventional estimation methods, such as the ordinary least square. It provides summary statistics on both the central part and the tails of the distribution of the response variable, allowing for a more complete investigation of the influence of specific covariates.

The quantile regression technique was used to compute a set of regression functions, each corresponding to a different quantile of the distribution of conditional volatility. Quantile regression produces similar results to OLS regression but QR is more robust to non-normal errors and outliers (Koenker and Bassett, 1978), while OLS can be inefficient if errors are highly non-normal. Furthermore, it can easily compare regression coefficients of specific quantiles to least square estimates. The interpretation is very similar: a one-unit increase in the predictor variable associated to the estimated coefficient produces a change in the dependent variable expressed by the coefficient obtained for the specific quantile of the response variable.

The determinants of EPS and ROE were verified through multiple linear regression in two firm performance equations. This study uses the following models to analyze the firm performance of top listed companies on SET with respect to specific determinants that emphasize six financial instruments (TOAT, P/E ratio, B/M ratio, INTE ratio, SGAE and firm SIZE). The model examines the composition on firm performance (FP) as follows:

$\mathrm{FP}=\mathrm{f}(\mathrm{TOAT}, \mathrm{P} / \mathrm{E}$ ratio, $\mathrm{B} / \mathrm{M}$ ratio, INTE ratio, $\mathrm{SGAE}, \mathrm{SIZE})$

When:

FP $\quad=\quad$ Firm performance represented by EPS and ROE 
TOAT = Tool in measuring and managing to evaluate the efficiency of a company's sales or revenue related to the value of its assets.

Company's sales.

$$
\left[\frac{\text { Net sales }}{\text { Average assets }}\right]
$$

$\mathrm{P} / \mathrm{E}$ ratio $\quad=\quad$ The ratio for evaluating a company that measured its current price relative to the company's net profit.

$$
\left[\frac{\text { Share price }}{\text { Earnings per share }}\right]
$$

$\mathrm{B} / \mathrm{M}$ ratio = Indicator to measure and compare the company's value to its market value.

$$
\left[\frac{\text { Total assets - total liabilities }}{\text { (market stocks' }^{\prime} \text { price)(shareholders' equity }}\right]
$$

INTE ratio $=$ To determine the operational ability of a company to pay the interest of lending funds.

$$
\left[\frac{\text { Earnings before interest and taxes (EBIT) }}{\text { Interest expense }}\right]
$$

SGAE $\quad=\quad$ The operating costs for running a business to turn higher sales and profit for the company.

SIZE $\quad=\quad$ The scale or volume of the company's operation affects the performance and profitability of the firm. SIZE represented by total assets.

Detailed models with the two dependent variables and six independent variables are explained in the following.

Model 1:

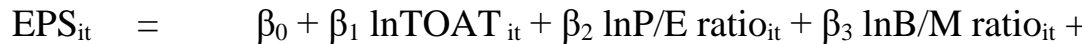

$$
\begin{aligned}
& \beta_{4} \operatorname{lnINTE} \text { ratio }_{\text {it }}+\beta_{5} \operatorname{lnSGAE} \mathrm{Bt}_{\mathrm{it}}+\beta_{6} \operatorname{lnSIZE} \mathrm{E}_{\mathrm{it}}+\varepsilon_{\mathrm{it}}
\end{aligned}
$$

Model 2:

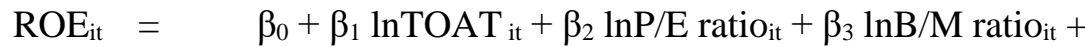

$$
\begin{aligned}
& \beta_{4} \operatorname{lnINTE} \text { ratio }_{\mathrm{it}}+\beta_{5} \operatorname{lnSGAE} \mathrm{it}_{\mathrm{it}}+\beta_{6} \operatorname{lnSIZE_{\mathrm {it}}}+\varepsilon_{\mathrm{it}}
\end{aligned}
$$


Models 1 and 2 are estimated to examine the determinants of different firm-specific parameters on firm performance through different types of firm-specific variables. The quantile regression approach was employed in this study and an attempt has been made to compare it with simple OLS estimates. Firm performance, dependent variable, used profitability (EPS and ROE) to measure firm performance. Similarly, the determinants of firm performance and independent variables chosen in this study were to use the logarithm of the annual data to measure this performance. The reason for this decision was to take advantage of statistical tools to improve on features that are normally distributed when obtaining data.

\section{Empirical Results}

The correlation analysis employed in this study is shown in Table 2 and the statistics summary is exhibited in Tables 3 to 5 . The overall findings show the existence of a firm's performance and the firm performance determinant exist among Thai listed firms. The term robustness refers to the strength of a statistical model; operational ability is the process of building firm performance that encourage a firm to create value for decision of investors, shareholders, and the economy in competitive markets.

\subsection{Correlation matrix}

The Pearson's correlation matrix was used to check multicollinearity problems, and the results are reported in Table 2. The overall values of the coefficients are below the value of 0.80 , suggesting that variables of interest are not highly correlated. Our argument is consistent with Gujarati (1995), who states that a multicollinearity problem is said to exist when the correlation between variables is higher than the threshold value of 0.80 .

Table 2. Correlation matrix

\begin{tabular}{|c|c|c|c|c|c|c|c|c|}
\hline Variables & EPS & ROE & $\operatorname{lnTOAT}$ & $\begin{array}{l}\ln \mathrm{l} / \mathrm{E} \\
\text { ratio }\end{array}$ & $\begin{array}{l}\ln \mathrm{B} / \mathrm{M} \\
\text { ratio }\end{array}$ & $\begin{array}{l}\text { lnINTE } \\
\text { ratio }\end{array}$ & $\operatorname{lnSGAE}$ & $\ln \mathrm{SIZE}$ \\
\hline EPS & 1 & & & & & & & \\
\hline ROE & $.132 * *$ & 1 & & & & & & \\
\hline $\operatorname{lnTOAT}$ & -.065 & -.052 & 1 & & & & & \\
\hline $\begin{array}{l}\operatorname{lnP} / \mathrm{E} \\
\text { ratio }\end{array}$ & $-.342 * *$ & -0.38 & $-.253 * *$ & 1 & & & & \\
\hline $\begin{array}{l}\operatorname{lnB} / \mathrm{M} \\
\text { ratio }\end{array}$ & $.131 * *$ & .028 & $-.119 * *$ & $-.453 * *$ & 1 & & & \\
\hline $\begin{array}{l}\text { lnINTE } \\
\text { ratio }\end{array}$ & -.034 & -.033 & .077 & $.143 * *$ & $-.236 * *$ & 1 & & \\
\hline $\operatorname{lnSGAE}$ & $.322 * *$ & .077 & $.250 * *$ & $-.372 * *$ & $.310 * *$ & $-.296 * *$ & 1 & \\
\hline $\operatorname{lnSIZE}$ & $.463 * *$ & $.104 *$ & $-.292 * *$ & $-.303 * *$ & $.467 * *$ & $-.328 * *$ & $.703 * *$ & 1 \\
\hline
\end{tabular}

Note: ** and $*$ shows significance at the 0.05 and 0.01 level

Source: Own study. 
The correlation analysis results show that multicollinearity is not a severe issue for the proposed model variables. The results indicate moderate correlation between the firm's performance and firm's performance determinants.

\subsection{Ordinary Least Square and Quantile Regression Analysis}

The study further applied stepwise multiple regression to explore the relationship between firm's performance, measured by EPS and ROE; specific firm performance determinants consisted of TOAT, $\mathrm{P} / \mathrm{E}$ ratio, $\mathrm{B} / \mathrm{M}$ ratio, interest coverage ratio (INTE ratio), SGAE, and firm SIZE.

The results of stepwise multiple regression of firm performance represented by EPS are shown in Model 1 in Table 3; the results show that both P/E ratio and B/M ratio have a negative relationship with EPS and this is significant at a 0.01 level. This implies that the increase in $\mathrm{P} / \mathrm{E}$ ratio and $\mathrm{B} / \mathrm{M}$ ratio leads to an increase in the perception of the efficiency of a firm, which would negatively impact EPS. INTE ratio and firm SIZE were found to have a positive relationship with EPS at a 0.01 significant level. Further, the stepwise multiple regression analysis of firm performance represented by ROE is shown in Model 2 in Table 3. The regression result demonstrates that only one specific firm determinant-firm SIZE - has a positive relationship with firm performance represented by ROE with a significance level of 0.05 .

As shown in Table 3, overall, Model 1 is statistically significant, with a F-statistic of 56.401 , a p-value of 0.000 , and with R-squared at 0.308 . Model 2 is statistically significant with F-statistic value 5.606, a p-value of 0.018 , and with R-squared at 0.011 .

$\mathrm{P} / \mathrm{E}$ ratio plays an essential role in both academic research and investment practices. It has been found to reflect the market's expectation of a firm's future growth and is associated with firm performance and risk. A high P/E ratio could mean that a company's stock price is overvalued; many investors will consider that it is better to buy shares in companies with a lower $\mathrm{P} / \mathrm{E}$ ratio because this means they are paying less for each capital of earnings they receive. Specifically, the theories predict that $\mathrm{P} / \mathrm{E}$ ratio is negatively correlated with expected rate of return. This result is consistent with the result of an empirical study carried out by Jitmaneeroj (2017b).

The result showed that stock investors might consider companies with a low $\mathrm{P} / \mathrm{E}$ ratio than companies holding a high $\mathrm{P} / \mathrm{E}$ ratio. Researchers such as Leong et al. (2009) investigated portfolio strategies. The results determined that investors were considered on stock valuation (low P/E ratio firms) and value sentiment. EPS is one of the many indicators that investors could use to buy stocks and would be a better company in terms of firm performance indicators. 
In sum, P/E ratio is an indicator of fundamental factors, but it also invites investors' sentiment in expecting companies to increase their EPS as a result. Likewise, the $\mathrm{B} / \mathrm{M}$ ratio indicates investors' views and considerations on the value of a company.

Therefore, a company's market value reflects the value of the company, which is determined by comparing its book value to its market value. High B/M ratio (where $\mathrm{B} / \mathrm{M}>1$ ) companies exhibit rather financially distressed fundamentals and so their stocks can be characterized as riskier compared to those of other companies that trade in the same market. Based on market or public views, investors are interested in investing in a company when it reflects good fundamental performance $(\mathrm{B} / \mathrm{M}$ ratio is low) so that the stock price will show a higher price and have a relatively lower additional capital payment because the stock is sold so it cannot be priced over its nominal value. The result also supports the findings of a recent study by de Vasconcelos and Martins (2019), which suggests that a company's B/M ratio should be less than $1(\mathrm{~B} / \mathrm{M}$ ratio < 1$)$ concept. The authors document that a higher $\mathrm{B} / \mathrm{M}$ ratio is statistically significant to the negative relationship with future dividend growth rate. Constantinou et al. (2017) support that a firm's growth rate of assets has a statistically significant negative relationship with the strong predictors of the future returns (B/M ratio) of Greek listed firms.

Further, the INTE ratio showed a positive relationship with EPS at a 0.01 significant level. Results show that the interest payment on business debt (INTE ratio) has a positive relationship on firm performance. Overall, the results suggest that a company's ability to meet its interest obligations is an aspect of its solvency and is, thus, an important factor in the return for shareholders (EPS). The results are in line with previous studies, such as Bodhanwala and Bodhanwala (2018), who investigated the link between corporate sustainability (total assets, total debt-toequity, and revenue growth) and the profitability performance of Indian firms. The results show that firm profitability consists of ROE, and EPS has a positive and significant relationship with the firm's sustainability. This analyzes companies that perform highly in terms of a company's core operating profit.

Similarly, Adenugba et al. (2016) confirm that financial leverage and reflecting on the amount of debt, has a positively significant effect on a firm's high value performance. All in all, INTE ratio indicator, known as core determinant on firms' performance in the private sector, is importantly financial measurements used to determine firm performance's important figure not only for creditors, but also for shareholders and investors.

Finally, SIZE was found to have a positive relationship with both EPS and ROE with 0.01 and 0.05 significant levels, respectively, which means that a percentage rise in SIZE is associated with a 3.186 percent increase in EPS. Likewise, the positive relationship between SIZE and ROE - which represents a percentage rise in SIZE is associated with about a 0.833 percent increase in ROE. The result also supports the previous findings of Kotey et al. (2021), who confirm that firm size increments 
positively affect stakeholder and firm performance. This finding was also confirmed by Ayaz et al. (2021). The distinguished results point out that firm size can significantly improve firm performance.

Liargovas and Skandalis (2010) and Akotey et al. (2013) confirm that firm size has a significant impact on a firm's competitiveness measured by ROE. So, the distinguished indicator of most successful companies, SIZE, is not only a firm performance determinant through a company's net profit but also from an investor's perspective on the stock market. Investors also consider a dividend payment (EPS) as a sign of a company's strength and a sign that management has positive expectations for future business performance and earnings. Both EPS and earnings (ROE) indicate that some of its profits go directly to shareholders, sending a signal to the stock market and reliable and efficient firm operations.

Table 3. OLS regression result of firm performance represented by EPS and ROE.

\begin{tabular}{|c|c|c|c|c|}
\hline \multirow[t]{3}{*}{ variables } & \multicolumn{2}{|c|}{$\begin{array}{l}\text { Model } 1 \\
\text { Dependent Variable, } \\
\text { Earnings per share (EPS) }\end{array}$} & \multicolumn{2}{|c|}{$\begin{array}{l}\text { Model } 2 \\
\text { Dependent Variable, } \\
\text { Return on equity (ROE) }\end{array}$} \\
\hline & Coefficients & & Coefficients & \\
\hline & Coefficient & p-value & Coefficient & p-value \\
\hline Intercept & -28.800 & 0.000 & -8.454 & 0.025 \\
\hline $\ln \mathrm{P} / \mathrm{E}$ ratio & -2.705 & $0.000 * * *$ & & \\
\hline $\operatorname{lnB} / \mathrm{M}$ ratio & -1.711 & $0.000 * * *$ & & \\
\hline lnINTE ratio & 0.349 & $0.001 * * *$ & & \\
\hline $\operatorname{lnSIZE}$ & 3.186 & $0.000 * * *$ & 0.833 & $0.018 * *$ \\
\hline $\mathrm{R}^{2}$ & 0.308 & & 0.011 & \\
\hline Adjusted $\mathrm{R}^{2}$ & 0.302 & & 0.009 & \\
\hline F-statistic & 56.401 & & 5.606 & \\
\hline Prob. (F-statistic) & 0.000 & & 0.018 & \\
\hline $\mathrm{Nb}$. of firms, & 100 & & 100 & \\
\hline $\begin{array}{ll}\mathrm{Nb} . & \text { of } \\
\text { observations }\end{array}$ & 513 & & 513 & \\
\hline
\end{tabular}

Note: Significant level; $* * * p<0.01, * * p<0.05$ and $* p<0.1$

Source: Own study.

In statistics, an outlier is a condition that occurs when a data point is significantly different to other observations. Outliers can change the meaning of the data. This research used the quantile regression approach $(\mathrm{QR})$ to examine the relationship between firm performance, and firm operating determinants of performance comprised of TOAT, P/E ratio, B/M ratio, INTE ratio, SGAE, and SIZE. QR provides summary statistics on both the central part and the tails of the distribution of the response variable and is more robust to non-normal errors and outliers (Hao and Naiman, 2007). The benefit of quantile regression is that the relationship between independent (EPS and ROE) variables, and the varied components of the distribution channel related to the dependent variable, are examined. The quantile regression results of firm performance are exhibited in Tables 4 and 5 . 
Table 4. Quantile regression results of firm performance represented by EPS

\begin{tabular}{|c|c|c|c|c|c|c|}
\hline \multirow[t]{3}{*}{ Variables } & \multicolumn{6}{|c|}{ Model 1. Dependent Variable, Earnings per share (EPS) } \\
\hline & \multicolumn{2}{|c|}{$Q=0.25$} & \multicolumn{2}{|c|}{$Q=0.50$} & \multicolumn{2}{|l|}{$\mathrm{Q}=0.75$} \\
\hline & Coefficient & p-value & Coefficient & p-value & Coefficient & p-value \\
\hline Intercept & 0.264 & $0.000 * * *$ & 0.362 & $0.000 * * *$ & 0.415 & $0.000 * * *$ \\
\hline $\operatorname{lnTOAT}$ & 0.003 & 0.328 & 0.009 & 0.148 & 0.026 & $0.066^{*}$ \\
\hline $\operatorname{lnP} / \mathrm{E}$ ratio & -0.150 & $0.000 * * *$ & -0.151 & $0.000 * * *$ & -0.100 & $0.000 * * *$ \\
\hline $\operatorname{lnB} / \mathrm{M}$ ratio & -0.148 & $0.000 * * *$ & -0.162 & $0.000 * * *$ & -0.097 & $0.000 * * *$ \\
\hline $\begin{array}{l}\operatorname{lnINTE} \\
\text { ratio }\end{array}$ & 0.002 & $0.035 * *$ & 0.005 & $0.001 * * *$ & 0.008 & $0.041 * *$ \\
\hline $\operatorname{lnSGAE}$ & 0.010 & $0.006 * * *$ & 0.004 & 0.535 & 0.022 & 0.175 \\
\hline $\operatorname{lnSIZE}$ & -0.009 & $0.010 * *$ & -0.012 & 0.101 & -0.031 & $0.064 *$ \\
\hline Pseudo & 0.089 & & 0.147 & & 0.249 & \\
\hline Square & & & & & & \\
\hline $\begin{array}{l}\mathrm{Nb} . \\
\text { firms, }\end{array}$ & 100 & & 100 & & 100 & \\
\hline $\begin{array}{l}\mathrm{Nb} \text { of of } \\
\text { observations }\end{array}$ & 513 & & 513 & & 513 & \\
\hline
\end{tabular}

Note: Significant level; $* * * p<0.01, * * p<0.05$ and $* p<0.1$

Source: Own study.

Table 5. Quantile regression results of firm performance represented by $R O E$

\begin{tabular}{|c|c|c|c|c|c|c|}
\hline \multirow[t]{3}{*}{ Variables } & \multicolumn{6}{|c|}{ Model 2 Dependent Variable, Return on equity (ROE) } \\
\hline & \multicolumn{2}{|c|}{$\mathrm{Q}=0.25$} & \multicolumn{2}{|c|}{$\mathrm{Q}=0.50$} & \multicolumn{2}{|l|}{$\mathrm{Q}=0.75$} \\
\hline & Coefficient & $\mathrm{p}$-value & Coefficient & $\mathrm{p}$-value & Coefficient & $\mathrm{p}$-value \\
\hline Intercept & -6.298 & $0.000 * * *$ & -8.460 & $0.000 * * *$ & -29.150 & $0.000 * * *$ \\
\hline $\operatorname{lnTOAT}$ & 0.285 & $0.000 * * *$ & 0.024 & 0.840 & -0.934 & $0.001 * * *$ \\
\hline $\operatorname{lnP} / \mathrm{E}$ ratio & -0.565 & $0.000 * * *$ & -1.326 & $0.000 * * *$ & -2.173 & $0.000 * * *$ \\
\hline $\operatorname{lnB} / \mathrm{M}$ ratio & -0.161 & $0.016 * *$ & -0.265 & $0.017 * *$ & -1.346 & $0.000 * * *$ \\
\hline $\begin{array}{l}\text { lnINTE } \\
\text { ratio }\end{array}$ & 0.161 & $0.000 * * *$ & 0.265 & $0.000 * * *$ & 0.468 & $0.000 * * *$ \\
\hline $\operatorname{lnSGAE}$ & 0.093 & 0.268 & 0.045 & 0.745 & 0.888 & $0.007 * * *$ \\
\hline $\operatorname{lnSIZE}$ & 0.645 & $0.000 * * *$ & 1.019 & $0.000 * * *$ & 2.413 & $0.000 * * *$ \\
\hline $\begin{array}{ll}\text { Pseudo } & \mathrm{R} \\
\text { Square } & \end{array}$ & 0.086 & & 0.147 & & 0.249 & \\
\hline $\begin{array}{l}\mathrm{Nb} . \quad \text { of } \\
\text { firms, }\end{array}$ & 100 & & 100 & & 100 & \\
\hline $\begin{array}{l}\mathrm{Nb} . \quad \text { of } \\
\text { observations }\end{array}$ & 513 & & 513 & & 513 & \\
\hline
\end{tabular}

Note: Significant level; $* * * p<0.01, * * p<0.05$ and $* p<0.1$

Source: Own study.

The quantile regression method was used to analyze the proposed model to describe the conditional distribution of the dependent variable, EPS, and ROE. The analysis considered three quantile interval ranges: $Q=0.25, Q=0.50$, and $Q=0.75$, presented in Tables 4 and 5. These two tables report the estimated results of three different quantile regression models by investigating the relationship between firm 
performance (EPS) and (ROE) and the determinant of firm performance. The Pseudo $\mathrm{R}^{2} \mathrm{Q}$ statistics indicate that the model, as fitted, explains the variability in the EPS and ROE quantile regression models.

At first, the $\mathrm{P} / \mathrm{E}$ ratio appears to be the highest important factor affecting firm performance. The results indicate that $\mathrm{P} / \mathrm{E}$ ratio tends to have a powerful negative impact on both EPS and ROE in the quantile regression approach, with three different quantiles of firms at a $p<0.01$ level, and it also has a negative impact on EPS in the OLS regression approach at a $\mathrm{p}<0.01$ level. This indicates that companies with low EPS and ROE are less impacted than companies with high EPS and ROE in a negative relationship. In other words, a percentage decrease in the P/E ratio of companies with lower EPS and ROE tend to show less of an increase in EPS and ROE than in companies with higher EPS and ROE. This finding supports that the $\mathrm{P} / \mathrm{E}$ ratio is negatively correlated with the expected rate of return from a company (EPS) because many investors pay less for every capital of earnings that they receive from the company. In particular, stock investors might consider companies with a low $\mathrm{P} / \mathrm{E}$ ratio than companies with a high $\mathrm{P} / \mathrm{E}$ ratio.

The $\mathrm{B} / \mathrm{M}$ ratio is clearly an essential factor that affects firm performance. The $\mathrm{QR}$ of all quantiles estimate a uniform capture on $\mathrm{B} / \mathrm{M}$ ratio as true determinants of firm performance in both EPS and ROE. The impact of the B/M ratio on EPS is greater on firms that are at the 0.25 and 0.50 quantiles but is smaller on the 0.75 quantiles of firms. In other words, $\mathrm{B} / \mathrm{M}$ ratio has a more robust impact on EPS in lower quantile firms $(\beta=-0.148$ and $\beta=-0.162)$ than in higher quantile firms $(\beta=-0.097)$. The $\mathrm{B} / \mathrm{M}$ ratio has less impact on the $\mathrm{ROE}$ of lower quantile firms, but has a greater impact on higher quantile firms. This variable was also significant on the negative relationships with EPS and ROE of all quantile regression approach at a $p<0.05$ level and has a significantly negative impact with the EPS of the OLS model.

Interest coverage ratio (INTE ratio) is also the main determinant on firm performance for both EPS and ROE. Results indicate that the INTE ratio has a lower influence on low quantile firms than in high quantile firms with a positive significance of $\mathrm{p}<0.05$ level. In other words, the effect of INTE ratio with companies with lower EPS and ROE is weaker than for companies with higher EPS and ROE. There is a 1 percent increase in the INTE ratio of lower EPS and ROE company, which tends to have a weaker increase in EPS and ROE than companies with higher EPS and ROE. Therefore, a higher ratio indicates that companies have the improved capacity to cover their debt interest expenses with its companies' operating performance generating income.

According to the quantile regression results, SIZE has had a consistently positive impact on firm performance, represented by ROE, OLS, and all quantile regression approaches, at $\mathrm{p}<0.05$ and $\mathrm{p}<0.01$ level, respectively. This result points out that companies with low ROE are less impacted and have a more positive relationship than companies with a high ROE. SIZE has a is substantially negative relationship ( $\beta$ 
$=-0.009$ and $\beta=-0.031$ ) with the EPS of small and large quantiles with a significance level of $\mathrm{p}<0.1$. The negative relationship indicates that the total assets (firm size) point out the total number of assets or additional investments owned by small and large companies, because total assets are resources with an economic value to generate future benefits. Small and large quantile firms with a stream of income may be more capable of additional investments by focusing on the allocation of productivity such as investment in assets and research and development (R\&D).

Both companies with low and high EPS are struggling to access more financial heath and they must grow their performance by raising the investment lead to lower net profit and finally to impact on EPS. Therefore, this study's results conceptualize that small and large quantile companies (low EPS companies and high EPS companies) have a negative relationship between SIZE and EPS. However, companies of all quantiles have positive relationships with SIZE and ROE.

Finally, two independent variables, TOAT, and (SGAE), showed no significance in the OLS model. While the quantile regression model that TOAT has a positive impact on firm performance measured by EPS $(\beta=0.026)$ at the highest quantile of firms with a significance level of $\mathrm{p}<0.1$. TOAT has a positive impact on firm performance by $\operatorname{ROE}(\beta=0.285)$ at the $25 \%$ quantile (lower ROE of companies) but has a negative impact at the $75 \%$ quantile (higher ROE of companies) with a significant level of $p<0.01(\beta=-0.934)$. The results explain that TOAT is essential for management through the use of its assets to generate value in the company's revenues and profit, especially for a company with high EPS and ROE. Further, SGAE is positively significant $(\beta=0.010)$ with EPS at a $p<0.01$ level at only the $25 \%$ quantile of companies and has a positive relationship $(\beta=0.888)$ with the ROE of the $75 \%$ quantile of companies at a $p<0.01$ level.

\section{Conclusion}

Performance measurement may depend on the firm's management, which operates to generate revenue and profit (Manogna et al., 2021; Fara and Supartika, 2016). Company operations are running funds and debt from various investors by focusing on investing in additional assets to maximize the return for investors and shareholders. B/M ratio and SIZE are key financial indicators for motivating firm operation improvement to respond to firm performance.

Obviously, following the results explained in the preceding section, the $\mathrm{B} / \mathrm{M}$ ratio certainly has a powerful impact on the negative relationship between the firm's performance in all quantiles, including the OLS model. In addition, quantile regression indicates that the effect of the $\mathrm{B} / \mathrm{M}$ ratio on companies with low EPS and ROE is lower than companies with high EPS and ROE. Investors consider the B/M ratio value to evaluate whether a company's stock is over or undervalued by comparing the market price of all shareholder with the net assets of the company. 
Therefore, $\mathrm{B} / \mathrm{M}$ ratio is a robust indicator to determine firm operation and performance. One of the main indicators relating to asset management is SIZE (Kotey et al., 2021; Bodhanwala and Bodhanwala, 2018), which has a strongly positive impact on firm performance, especially on the ROE of all of the quantiles of companies. Interestingly, SIZE has a substantially negative relationship with EPS, particularly in companies with low and high EPS. These results reveal that companies with low EPS are struggling to improve their practices and productivity by investing additional assets so they can focus more on profit. Companies with a high EPS are making up a larger and larger share of the company's growth and profit. Because of this, additional business expenses may be of lower net income in the short term, reflected by the level of EPS, but potentially increasing long-term income and profit.

As well as the firm performance indicator, the financial instrument that can be used to evaluate the performance of a company by comparing stock prices and company's earnings is the $\mathrm{P} / \mathrm{E}$ ratio. The $\mathrm{P} / \mathrm{E}$ ratio has always been a most attractive indicator of firm value for both shareholders and investors on the stock market. The research results show that the P/E ratio has a stronger negative impact on both EPS and ROE over the different quantile models. Low P/E might indicate that the current stock price is low compared to shareholders' earnings (EPS). The $\mathrm{P} / \mathrm{E}$ ratio helps investors determine the market's stock prices, as compared to the shareholders' earnings (EPS), and the $\mathrm{P} / \mathrm{E}$ ratio was also associated with the current ROE.

Goodman and Peavy III (1986) conclude that a low P/E can indicate that a company may either be currently undervalued or that the company is doing outstandingly well in relation to the trends of its past performance. In practice, the $\mathrm{P} / \mathrm{E}$ ratio will be used as an instrument to compare different companies within the same industry and with similar characteristics rather than comparing industries on the stock market.

The overall INTE ratio model was statistically significant as a good predictor, significant in all quantiles for firm performance. Results show that the INTE ratio has a lower impact in low quantile firms than in high quantile firms. As firms increase their productivity, their profits and debts are expected to increase in both return and costs. It may be that the lower profit the firm is, the less diverse the activity will be, therefore, the impact of interest expenses is also less across the same class. In contrast, higher quantile firms (higher EPS and ROE) reflect the strong underlying conditions and productivity that tend to meet an increase in interest expenses. The INTE ratio determines a company's ability to cover the interest expenses on its debt using its operating income. A higher ratio indicates that a company has better capacity to cover its interest expenses as the greater the interest expense, the greater the potential impact on profitability.

In line with business management theory, TOAT and SGAE, showed insignificance with the OLS model. However, TOAT has a positive impact on firm performance for companies with high EPS and ROE. This indicates that these companies have 
management that has the strong ability to use assets to generate income. SGAE has a positive impact on firm performance at the $25 \%$ and $75 \%$ quantiles, due to managerial executive teams, and can measure managerial flexibility to create a company that can better generate operating profit.

\section{Implication}

For managers and those of firm operation, effective company performance is essential to business operation within all industries. A company's performance is measured through its resulting earnings. Hence, a company should actively try to increase performance by obtaining a high amount in earnings. The outstanding performance measurements of a firm, such as financial indicator, are EPS and have ROE. High earnings obtained by a firm are more attractive for investors than low earnings. Presented in a financial statement, earnings can influence a firm's decision making (Al-Absy et al., 2020). Key financial factors that determine firm performance and profitability are the many different financial instruments.

Profitability is also the key to analyzing how effectively and efficiently a business can manage its total assets to produce income. All businesses should be operating with an efficient utilization of assets at full capacity. The B/M ratio assesses a company's value by comparing its book value to its market value. Overvalued shares will have a higher market value than book value, and undervalued shares will have a lower market value than book value.

For investing decision, investors consider the fundamental analysis as any indication of the company's ability to grow, companies will grow in value, which will allow them to sell their future stocks for a higher price. Fundamental analysis helps investors predict long-term trends of a company's operation in the market. In short, investors and analysts use these values to determine a company's profitability as current performance to predict its future earnings and performance for making decisions to buy company stocks (Ernayani and Robiyanto, 2016; Purwanti and Natser, 2016).

Debt ratio measures a firm's ability to repay long-term debt associated with its operation. This ratio is used by both creditors and investors to assess the risks of lending capital to a company when a higher coverage ratio would be more appropriate. It indicates that a company's high financial performance is due to the firm making enough money to pay its interest obligations through earnings or the company's stability. Fundamental analysis reflects whether a company manages its operation by producing and selling its goods and services and driving stock prices (market value) based on the company's earnings and profitability.

As a whole, the board of directors, one of the most important determinations of a companies' success, bears a legal responsibility to govern and monitor the fundamental analysis from a financial statement. A powerful executive team not 
only motivates everyone in the organization to propel the organization's capability, but also evaluate business operations and forward strategies to finally achieve higher firm performance.

\section{References:}

Abor, J. 2005. The effect of capital structure on profitability: an empirical analysis of listed firms in Ghana. The Journal of Risk Finance, 6(5), 438-445.

Adenugba, A.A., Ige, A.A., Kesinro, O.R. 2016. Financial leverage and firms' value: A study of selected firms in Nigeria. European Journal of Research and Reflection in Management sciences, 4(1), 14-32.

Ahmed Al-Dujaili, M.A. 2013. Study of the relation between types of the quality costs and its impact on productivity and costs: a verification in manufacturing industries. Total Quality Management \& Business Excellence, 24(3-4), 397-419.

Akotey, J., Sackey, F., Amoah, L., Manso, R. 2013. The financial performance of life Insurance companies in Ghana. The Journal of Risk Finance, 14(3), 286-302.

Alarussi, A.S., Alhaderi, S.M. 2018. Factors affecting profitability in Malaysia. Journal of Economic Studies, 45(3), 442-453.

Al-Absy, M.S.M., Ismail, K.N.I.K., Chandren, S., Al-Dubai, S.A.A. 2020. Involvement of board chairmen in audit committees and earnings management: Evidence from Malaysia. The Journal of Asian Finance, Economics, and Business, 7(8), 233-246.

Anderson, M.C., Banker, R.D., Janakiraman, S.N. 2003. Are selling, general, and administrative costs "sticky"? Journal of accounting research, 41(1), 47-63.

Anderson, K., Brooks, C. 2006. Decomposing the price-earnings ratio. Journal of Asset Management, 6(6), 456-469.

Araújo, R.C.D.C., Machado, M.A.V. 2018. Book-to-market ratio, return on equity and Brazilian stock returns. RAUSP Management Journal, 53(3), 324-344.

Asian Development Bank. 2021. Country Partnership Strategy. Thailand, 2021-2025 Prosperity and Sustainability through Knowledge and Private-Sector-Led Growth, 2 -5 .

Ayaz, M., Zabri, S.M., Ahmad, K. 2021. An empirical investigation on the impact of capital structure on firm performance: Evidence from Malaysia. Managerial Finance, 47(8), 1107-1121.

Bayrakdaroğlu, A., Yalçin, N. 2012. Strategic financial performance evaluation of the Turkish companies traded on ISE. Ege Academic Review, 12(4), 529-539.

Berko, O., Damoah, O. 2013. Strategic factors and firm performance in an emerging Economy. African Journal of Economic and Management Studies, 4(2), 267-287.

Biadacz, R. 2020. Quality cost management in the SMEs of Poland. The TQM Journal, 33(7), 1-38.

Bodhanwala, S., Bodhanwala, R. 2018. Does corporate sustainability impact firm profitability? Evidence from India. Management decision, 56(8), 1734-1747.

Camino-Mogro, S., Bermúdez-Barrezueta, N. 2019. Determinants of profitability of life and non-life insurance companies: evidence from Ecuador. International Journal of Emerging Markets, 14(5), 831-872.

Campanella, J. 1999. Principles of quality costs: Principles, implementation, and use. In: ASQ World Conference on Quality and Improvement Proceedings, 507. American Society for Quality, 507

Clubb, C., Naffi, M. 2007. The usefulness of book-to-market and ROE expectations 
for explaining UK stock returns. Journal of Business Finance \& Accounting, 34(1/2), 1-32.

Constantinou, G., Karali, A., Papanastasopoulos, G. 2017. Asset growth and the crosssection of stock returns: evidence from Greek listed firms. Management Decision, 55(5), 826-841.

Deng, H., Hu, R., Huang, R., Pray, C., Jin, Y., Li, Z. 2017. Attitudes toward GM foods, biotechnology R\&D investment and lobbying activities among agribusiness firms in the food, feed, chemical and seed industries in China. China Agricultural Economic Review, 9(3), 385-396.

De Vasconcelos, L.N.C., Martins, O.S. 2019. Value and growth stocks and shareholder value creation in Brazil. Revista de Gestão, 26(3), 293-312.

Di Bella, M.G., Norton, M.L., Ntamatungiro, M.J., Ogawa, M.S., Samake, I., Santoro, M. 2015. Energy subsidies in Latin America and the Caribbean: stocktaking and policy challenges. International Monetary Fund.

Dimitrantzou, C., Psomas, E., Vouzas, F. 2020. Future research avenues of cost of quality: a systematic literature review. The TQM Journal, 32(6), 1599-1622.

Erina, J., Lace, N. 2013. Commercial banks profitability indicators: empirical evidence from Latvia. IBIMA Business Review, 1-9.

DOI: $10.5171 / 2013.873515$.

Ernayani, R., Robiyanto, R. 2016. The effect of the cash flows, gross profit and company size on Indonesian stock returns (a study on the chemical and basic industry companies during the periods of 2009-2014). International Journal of Applied Business and Economic Research, 14(3), 1697-1709.

Fara, M., Supartika, N. 2016. Factors affecting profitability of small medium enterprises SMEs) firm listed in Indonesia stock exchange. Journal of Economics, Business and Management, 4(2), 132-137.

Gitman, L.J., Zutter, C.J. 2012. Principles of Managerial Finance, 13th ed. Addison.

Gujarati, D.N. 1995. Basic Econometrics, $3^{\text {rd }}$ ed. McGraw-Hill, New York.

Gunarathne, N., Samudrage, D. 2018. Analysis of the cost structure: perspectives from the manufacturing companies in Sri Lanka. Asia-Pacific Management Accounting Journal, 13(3), 197-223.

Hao, L., Naiman, D.Q., Naiman, D.Q. 2007. Quantile regression, No. 149. Sage.

Jitmaneeroj, B. 2017a. Does investor sentiment affect price-earnings ratios? Studies in Economics and Finance, 34(2), 183-193.

Jitmaneeroj, B. 2017b. The impact of dividend policy on price-earnings ratio: The role of conditional and nonlinear relationship. Review of Accounting and Finance, 16(1), 125-140.

Karadag, H. 2017. The impact of industry, firm age and education level on financial management performance in small and medium-sized enterprises (SMEs) evidence from Turkey. Journal of Entrepreneurship in Emerging Economies, 9(3), 300-314.

Katchova, A.L., Enlow, S.J. 2013. Financial performance of Publicly-Traded Agribusinesses. Agricultural Finance Review, 73(1), 58-73.

Katsampoxakis, I., Basdekis, H., Anathreptakis, K. 2015. How firm and market characteristics affect profitability: an empirical study. International Journal of Corporate Finance and Accounting, 2(1), 67-83.

Katsampoxakis, I., Basdekis, H., Anathreptakis, K. 2018. How the Greek crisis determined firm profitability and optimal debt ratio. In: Zopounidis, C., Christopoulos, A., Kalantonis, P. (Eds), Perspectives, Trends, and Applications in Corporate Finance and Accounting. IGI Global Publications, 1-31. 
Khan, M.T.I., Tan, S.H., Chong, L.L. 2017. Information sources and investing decisions-a path modeling approach. Managerial Finance, 43(8), 928-947.

Kiani, B., Shirouyehzad, H., Bafti, F.K., Fouladgar, H. 2009. System dynamics approach to analysing the cost factors effects on cost of quality. International Journal of Quality \& Reliability Management, 26(7), 685-698.

Koenker, R., Bassett, G.J. 1978. Regression quantiles. Econometrica, 46(1), 3350. Math. Rev. MR0474644 Zentralblatt MATH, 373.

Kotey, R.A., Akomatey, R., Kusi, B.A. 2021. Exploring the nonlinear effect of size on profitability: evidence from an insurance brokerage industry in an emerging market. African Journal of Economic and Management Studies, 12(3), 381-399.

Leong, K., Pagani, M., Zaima, J.K. 2009. Portfolio strategies using EVA, earnings ratio or book-to-market: Is one best? Review of Accounting and Finance, 8(1), 76-86.

Li, M.Y.L., Hwang, N.C.R. 2011. Effects of firm size, financial leverage and R\&D expenditures on firm earnings: an analysis using quintile regression approach. A Journal of Accounting, Finance and Business Studies, 47(2), 182-204.

Liargovas, P., Skandalis, K. 2010. Factors affecting firm competitiveness: the case of Greek Industry. European Industrial Journal, 2, 184-197.

Locke, P.R., Mann, S. 2005. Professional trader discipline and trade disposition. Journal of Financial Economics, 76(2), 401-444.

Malik, T.M., Khalid, R., Zulqarnain, A., Iqbal, S.A. 2016. Cost of quality: findings of a wood products' manufacturer. The TQM Journal, 28(1), 2-20.

Manogna, R.L., Mishra, A.K. 2021. Measuring financial performance of Indian manufacturing firms: application of decision tree algorithms. Measuring Business Excellence . DOI 10.1108/MBE-05-2020-0073

Modigliani, F., Miller, M.H. 1963. Corporate income taxes and the cost of capital: a Correction. The American Economic Review, 53(3), 433-443.

Newman, A., Gunessee, S., Hilton, B. 2012. Applicability of financial theories of Capital structure to the Chinese cultural context: a study of privately owned SMEs. International Small Business Journal, 30(1), 65-83.

Nunes, P.M., Serrasqueiro, Z.S., Leitao, J. 2010. Are there nonlinear relationships between the profitability of Portuguese service SME and its specific determinants? The Service Industries Journal, 30(8), 1313-1341.

Office of the National Economic and Social Development Council. 2019. Thai Economic Performance in Q4 and 2019 and Outlook for 2020. Nesdc Economic Report, 1-32.

Öner Kaya, E. 2015. The effects of firm-specific factors on the profitability of non-life insurance companies in Turkey. International Journal of Financial Studies, 3(4), 510-529.

Purwanti, D., Natser, G.I. 2016. Influence of the quality of accrual financial report information with the roles of accounting information system as an intervening factor. Jurnal Dinamika Akuntansi, 8(2), 84-97.

Sinthupundaja, J., Chiadamrong, N. 2015. Investigation of Thai manufacturing public firms' characteristics and financial strategies towards financial performances improvement. Journal of Economics, Business and Management, 3(3), 331-337.

Stimolo, M.I., Porporato, M. 2019. How different cost behaviour is in emerging economies? Evidence from Argentina. Journal of Accounting in Emerging Economies, 10(1), 21-47.

Tailab, M.M. 2014. Analyzing factors effecting profitability of non-financial U.S. Firms. Research Journal of Finance and Accounting, 5(22), 17-26.

Thomas, J., Zhang, H. 2006. Another look at P/E ratios. Yale School of Management. 
Working Paper, 1-36.

Tsiapa, M. 2021. Performance of large firms in Greece during the unstable period of 20112016: lessons from the weak parts of Europe. European Journal of Management and Business Economics, 31(1), 94-114.

Venezia, I., Nashikkar, A., Shapira, Z. 2011. Firm specific and macro herding by professional and amateur investors and their effects on market volatility. Journal of Banking and Finance, 35(7), 1599-1609.

Wang, Y., Wang, G. 2021. IPO underpricing and long-term performance in China: the perspective of price limit policy. Managerial Finance, 47(9), 1233-1252.

Warrad, L., Al Omari, R. 2015. The impact of turnover ratios on Jordanian services sectors' performance. Journal of modern accounting and auditing, 11(2), 77-85.

Wirjanto, T.S., Huang, A.G. 2010. Is China's P/E Ratio Too Low? Examining the Role of Earnings Volatility. Pacific-Basin Finance Journal, 1-40. DOI.org/10.2139/ssrn.16326.

Zafar, S.T., Khalid, S.M. 2012. A Comparative Evaluation of Financial Performance and Market Value of Maruti and Tata Company. Bookman International Journal of Accounts, Economics \& Business Management, 1(1), 7-16.

Zeitun, R., Saleh, A.S. 2015. Dynamic performance, financial leverage and financial crisis: evidence from GCC countries. EuroMed Journal of Business, 10(2), 147-162.

Zemba, S., Hendrawan, R. 2018. Does Rapidly Growing Revenues Always Produce An Excellent Company's Value? DCF \& P/E Valuation Assessment on Hospital Industry. In: Proceeding of International Seminar \& Conference on Learning Organization, 213-227. 